Canadian Food Studies

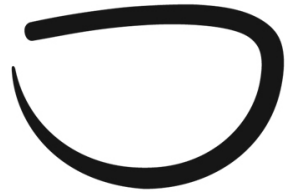

La Revue canadienne des études sur l'alimentation

Original Research Article

\title{
Food Counts: Food systems report cards, food sovereignty and the politics of indicators
}

\author{
Charles Z. Levkoe ${ }^{a^{*}}$ and Alison Blay-Palmer ${ }^{b}$ \\ ${ }^{a}$ Canada Research Chair in Sustainable Food Systems, Lakehead University, Ontario \\ ${ }^{b}$ Centre for International Governance Innovation Chair in Sustainable Food Systems, Wilfrid Laurier \\ University, Ontario
}

\begin{abstract}
The International Panel of Experts on Sustainable Food Systems recognized that "current systems will be held in place insofar as these systems continue to be measured in terms of what industrial agriculture is designed to deliver, at the expense of many other outcomes that really matter in food systems" (IPES-Food, 2016, p. 57). In response, they called for new food systems indicators rooted in social justice, support for local economies, ecological regeneration, and democratic engagement. This paper reflects on the ways that indicators can serve as a tool to understand the current state of food systems, challenge existing approaches, and (re)frame a future vision of equity and sustainability. Our analysis focuses on the development of Food Counts: A Pan-Canadian Sustainable Food Systems Report Card, a first attempt to bring together existing measures of social, environmental, and economic well-being to help researchers, policy makers, and practitioners examine food systems more comprehensively. The report card used a food sovereignty framework and an integrated systems perspective and makes connections to a global movement for collective social change. Beyond its practical value, and particularly in the context of Canada's development of a national food policy, our analysis illuminates the limited kinds of data available, the privileging of scientific expertise over traditional knowledge, the assumed value of certain indicators, and the reductionist nature of using data to represent complex food systems. We argue that while report cards can make visible numerous food systems' elements, they can also obscure diverse experiences, reinforcing unsustainable practices and policies.
\end{abstract}

Keywords: food sovereignty; food systems; indicators; report card; sustainability 


\section{Introduction}

Within Canada, there is growing concern about how food systems are organized and governed and who has the power to make decisions that impact people and the natural world. While governments are obliged to manage food systems in the public interest, there is growing evidence that benefits are unequally distributed. Controlled primarily by corporate interests, the systems that bring food to our plates privilege private economic interests over social and ecological well-being (Howard, 2016; Clapp \& Fuchs, 2009). Despite supplying large amounts of foods to global markets, the dominant food system is contributing to a host of negative outcomes, including: degradation of land, water and ecosystems (Sage, 2011; FAO, 1999); high levels of greenhouse gas emissions (GRAIN, 2011); persistent hunger and under-nutrition together with a rise in diet-related diseases (Tarasuk, Dachner, \& Loopstra, 2014); and the precarity of farmer and fisher livelihoods around the world (Beaulieu, 2015). Practical tools are needed to help understand the current state of Canadian food systems and to guide a fundamentally different way of governing food systems that can (re)frame a vision of health, equity, and sustainability.

In a recent report, the International Panel of Experts on Sustainable Food Systems (IPESFood) recognized that "current systems will be held in place insofar as these systems continue to be measured in terms of what industrial agriculture is designed to deliver, at the expense of many other outcomes that really matter in food systems” (IPES-Food, 2016, p. 57). In response, they called for the development of new indicators for sustainable food systems that are rooted in an alignment of social justice, support for local economies, ecological regeneration, and democratic engagement. Others have also identified the need to establish indicators to better understand how food systems function and to determine where to intervene (Blay-Palmer, Turner, \& Kornelson, 2008; Marsden, 2010). A food systems report card is one tool that brings together a range of indicators and can support several practical, reflective and visionary functions. Report cards can provide a lay of the land, act as a benchmark to inform a historical and contextual analysis as well as identify patterns that point towards future developments. They can also help to make visible gaps in existing data and identify areas requiring further research and examination. These tools are particularly relevant in Canada given the federal government's announcement in May 2016 to develop a Food Policy for Canada (Levkoe \& Wilson, 2017). Recognizing there is a lack of existing data to assess the state of Canada's food systems, a national report card would bring together a range of essential information, point to opportunities and gaps, and help monitor changes over time.

However, report cards are not politically neutral, with many revealing implicit bias towards promoting a narrow set of objectives and neoliberal logics (Hacking, 2007). Existing report cards on the state of food reveal significant limitations based on narrow foci and scale. For example, the Conference Board of Canada’s Food Report Card 2015 (Le Vallée \& Grant, 2016) and the Global Food Security Index (The Economist Group, 2016) presented at the World Economic Forum are both rooted within a primarily economic perspective; the Food Banks 
Canada’s annual Hunger Count Reports (Food Banks Canada, 2016) focus primarily on food access; and, the Diabetes Association of Canada linked food with particular health expenditures through their report The Economic Tsunami: The Cost of Diabetes in Canada (Diabetes Canada, 2009). Each of these contribute to a broader conversation, yet none of these reports focus on measuring or supporting the cross-cutting, multi-sectoral dimensions needed to assess the state of food systems. While comprehensive report cards do exist at the municipal or regional scale, we lack an assessment tool that takes a Pan-Canadian food systems approach with an integrated focus on social, economic, ecological, and political sustainability.

In this paper, we critically reflect on the ways that report cards can serve as a practical tool to understand the state of food systems, challenge current practices, and help to (re)frame our vision of a healthy, equitable and sustainable food system. These reflections draw on our collective experience developing Food Counts: A Pan-Canadian Sustainable Food Systems Report Card between 2016 and $2017^{1}$. Bringing together existing measures of social, environmental, and economic well-being, Food Counts was developed to help researchers, policy makers, and practitioners examine sustainable food systems at the national level. It uses a food sovereignty framework to embed food within an integrated systems perspective and makes connections to a global movement engaged in efforts towards progressive social and ecologic change. We argue that while report cards are a valuable tool that can make visible numerous food systems' elements, using indicators to represent complex systems can also obscure different food systems experiences and direct us towards and reinforce unsustainable practices and policies. In the following section, we explore the scholarly literature on measuring food systems and sustainability. We then describe the process of developing the Food Counts report card, along with some of the findings from this initiative, followed by a critical discussion about the opportunities and limitations of using indicators to represent food systems. Considering that the development of a national food policy will require establishing a monitoring and reporting system, we conclude with some suggestions for the kinds of indicators that could be tracked as well as recommendations for institutionalizing the responsibilities of a reporting body.

\section{Measuring sustainable food systems}

\section{Measuring sustainability}

Indicators are increasingly viewed as an essential part of informed decision-making (Hezri \& Dovers, 2005; Bell \& Morse, 2011). In general, indicators can be described as the quantification of social and ecological conditions and can be used to assess the historical and current state of affairs, and predict future trends. While the kinds of indicators vary widely, they are typically selected based on criteria that meet the needs of a specific project, program, or policy and are

${ }^{1}$ www.fledgeresearch.ca/foodcounts 
defined by their ability to evaluate a specific phenomenon (Tanguay, Rajaonson, Lefebvre, \& Lanoie, 2010; Schader et al., 2016). Many governments, organizations and researchers use indicators to inform decision-making; however, the value of individual indicators examined in isolation has faced criticism (Blay-Palmer et al., 2008). According to the IPES-Food (2015) “...a critical mass of evidence must be attained and transposed into policy recommendations in order to create the momentum for food systems reform” (p. 17). Key here is the idea that it is vital to bring together existing indicators to provide a more complete picture of the phenomenon under study, for example, food systems sustainability.

The United Nations Sustainable Development Goals (SDG) are arguably the most ambitious attempt to measure sustainability and to understand a range of considerations in developing adequate indicators. The SDGs were launched in 2015 and focus on human and ecological prosperity, which includes targets to be achieved by 2030. The process involves data collection from 193 member countries organized around seventeen sustainability goals measured by 244 indicators. The rationale for this ambitious project as asserted in the Sustainable Development Solutions Network report (2015) is that,

Effective SDGs and their targets will serve as a management tool to help countries develop implementation strategies and allocate resources accordingly. They will also serve as a report card to measure progress towards sustainable development and to help ensure the accountability of all stakeholders for achieving the SDGs. Indicators will be the backbone of monitoring progress towards the SDGs at local, national, regional, and global levels (p. 8).

In terms of implementation, the report goes on to explain,

The SDGs require annual reporting of high-quality data from all countries. This in turn will require much greater investments in building independent, impartial national statistical capacities and strengthening quality and standards...The SDGs will be goals for the world-applicable to all countries, as well as multiple, diverse actors. As such, the best input from business, science, academia, and civil society should be sought in their development, as well as in the development of the accompanying monitoring architecture (emphasis added, p. 8).

These are lofty expectations, and loaded with assumptions that need to be unpacked. While the proposed list of actors to be consulted is inclusive of all parts of society, in reality there is an uneven capacity for actors to engage based on disparate power. This discrepancy is most evident in the unequal wealth and resources between different countries but also in the limited resources available to civil society organizations and social movements in relation to the private sector in all countries. It is also important to consider the type of information being 
gathered. Technical indicators do not usually reflect traditional knowledge so the nature of the indicators, how information is gathered, and what knowledge is relevant are all points of tension (IPES-Food, 2015). Concern has been raised that the kinds of indicators used have the potential to further marginalize groups that are already struggling to be heard (Blay-Palmer et al., 2008; Bauler, 2015; Binimelis et al., 2015).

The assumption that indicators will be 'independent and impartial' reveals misplaced confidence in the objectivity of metrics. While indicators can play an important role, it is essential to consider their execution and associated outcomes. For example, recent approaches to food production that use Sustainable Intensification and Climate Smart Agriculture privilege technical innovation and scientific knowledge over social innovation and traditional/experiential knowledge (Climate Smart Agriculture CONCERNS, 2015). Similarly, indicators that adopt a narrow food security lens can lead to the conclusion that increasing production is the best solution for ensuring people have access to food while ignoring negative social and ecological implications (Patel, 2009). While they do deal with some dimensions of sustainability, these two examples use approaches that ignore the systemic impacts of climate change, food waste, and ecosystem decline and can push us further away from an integrative perspective.

These kinds of insights have led to the increasing recognition that the complexities of food demand a systems approach to capture interactions, understand feedback loops, and identify tradeoffs between the environment, the economy, political, cultural and social justice considerations (Ericksen et al., 2010a). Indicators can enlarge or narrow the lens we use to understand a set of challenges. To make these types of dynamics more apparent, Erickson argues, "more sophisticated analytical lenses are needed to comprehend both how food makes its way from 'field to fork', and how to frame policy that corrects for the negative social and environmental outcomes of food system activities” (p. 26). For example, research by Pullman, Maloni, \& Carter (2009) measuring the sustainability of firms in the food industry determined that only including environmental indicators missed important social and economic benefits. Despite recommending more diverse indicators, these authors acknowledge that capturing the complexities and interconnections inherent to sustainability is challenging. Garnett and Godfray (2012) confirm the importance of using indicators to measure sustainability from a systems perspective. Their research explored the contradictions in assumptions about sustainable intensification in the context of developing agricultural policy that integrates environmental, animal welfare, and health policy. Their findings suggest that developing a set of indicators that adopt a systems perspective could provide insights into interactions among policies, reflect specific goals, and guide the implementation of more targeted, successful policy.

Bauler (2015) suggests that indicators can help shape norms and conventions and can bridge knowledge gaps between policy, science, and society if understood as "boundary institutions" (41). He further contends that this steering of indicators to bridge knowledge gaps, find consensus regarding the usability of indicators across policy actors, and, ultimately, affect policy decisions should be seen as a political process, what he calls a "politics of policy indicators” (44). Directing policy tools and policy instruments at such a meta-level has been 
addressed by concepts such as reflexive governance (Beck, 2005), adaptive food system management (Ericksen et al., 2010b), and adaptive planning (Weber, 2006, 42). Bauler's ultimate concern is how indicators can be developed to have the most useful profile possible such that information is gathered and diffused in ways that impact policy decisions around sustainability. Consistent with the IPES-Food report (2015), he questions the ability of traditional forms of scientific/modernist knowledge to be usable across policy actor groups or to represent changing data about climate change in ways that are useful for policy decision making.

\section{Frameworks for measuring sustainable food systems}

In the context of sustainable food systems, Hamm (2015) prompts us to recognize what our dominant food system does in its current state and the alternatives we need to be considering for the future,

...we could take a step back and re-evaluate the current situation in the developed world for what it is - a global system of production and distribution that works well for relatively small numbers of people over a relatively short period of time within a given set of environmental and resource availability conditions... [it] doesn't work well when the environmental bill comes due. Nor does it seem to ensure food access and security for everyone.

Report cards and other knowledge-sharing tools tell stories through the indicators selected. Taken together, the indicators provide benchmarks and signal whether we are moving towards or away from the desired goals (Hezri \& Dovers, 2005; Tanguay et al., 2010; Binimelis et al., 2014). More important, the way that the analysis is shaped can have a significant impact on the results. According to the IPES-Food (2015),

Food systems initiatives at the interface of science, policy and practice must therefore unify in their diversity, together tracing out pathways to sustainable food systems. In doing so, conscious and continued reports will be needed to build on the transdisciplinary advances of recent decades. This will ensure that the emerging science of sustainable food systems is informed by the immense knowledge of practitioners, and appropriated by those to whom it seeks to be useful (p. 17).

Building from work on the right to food (Anderson, 2008; McIntyre, Herren, Wakhungu, \& Watson, 2009; FIAN, 2016; Forster \& Mathieson, 2016), the IPES-Food 2015 report proposes we connect silos to create an integrated, inclusive and empowering basis for food systems,

There has been a tendency to address the problems as individual pieces of the puzzle, and to overlook the power relations that play a 
major role in shaping these systems. And crucially, the knowledge of those affected by food systems problems has not been fully harnessed in framing the problems and diagnosing the solutions. The challenge, therefore, is to produce a joined-up picture of food systems and their political economy, and to do so in ways that reach across the scientific disciplines, and reach beyond the traditional bounds of the scientific community (p. 2).

This proposed analytical framework calls for extensive consultation to build and consult through iterative processes that engage across the food system in order to challenge the existing political economy of food and challenge existing power structures for transformation towards sustainability (IPES-Food, 2015, p. 3). A further goal is to foster a new transdisciplinary science of food systems, to break down silos in order to co-produce knowledge across the full range of food system actors (IPES-Food, 2015, p. 8). An example of this approach comes from members of the Wisconsin Foodshed Research Project (Kloppenburg, Lezber, De Master, Stevenson, \& Hendrickson, 2000) who explored attributes of food systems sustainability with a broad range of “ordinary” and “competent” people (p. 177). A series of fourteen attributes were abstracted from 323 data points grouped into clusters and described sustainable food systems as: ecologically sustainable, knowledgeable/communicative, proximate, economically sustaining, participatory, just/ethical, sustainable regulated, sacred, healthful, diverse, culturally nourishing, seasonal/temporal, value-oriented (associative) economics, and relational. While many of these attributes challenge conventional uses of the term sustainability, they also illuminate the multiple and interrelated dimensions of food systems with respect to a transformative project.

More recently, food sovereignty has gained significant traction among practitioners and researchers across the globe as a framing concept that moves considerations from a narrow focus on production, economics, or food and nutrition security to include the interrelationships between the environment and social justice (Patel, 2009; Wittman, Desmarais, \& Wiebe, 2010). Food sovereignty evolved from a collaborative dialogue among social movements in response to concerns that concepts of sustainability were being co-opted by both governments and corporations. As a master frame of global food movements, food sovereignty prioritizes "the right of peoples to healthy and culturally appropriate food produced through ecologically sound and sustainable methods, and their right to define their own food and agriculture systems" (Nyéléni Forum for Food Sovereignty, 2007). Food sovereignty pushes back against the economic growth and individualism fostered by the mainstream development paradigm and provides the basis for a global movement focused on food as a means for collective social change.

As an integrated, rights-based approach, food sovereignty has the potential to empower the most vulnerable in the food system and build collaboration across sectors, scales, and places. At the same time, food sovereignty is an evolving place-based concept and provides opportunities to establish interconnected priorities, actions and strategies between different regions. These principles have been adopted into legislation by several national governments 
including Mali in 2006, Nepal in 2007, Ecuador in 2008, Venezuela in 2008, Bolivia in 2009, and Nicaragua in 2009. Food sovereignty ideals have been formative for Brazilian food policy over the last decade. Constituent groups of the Civil Society Mechanism in the UN Food and Agricultural Organization Committee on Food Security have also adopted principles of food sovereignty to protect their right to food and land. This work is supported by international organizations including FIAN International and La Via Campesina as well as regional and continental food sovereignty alliances (e.g., Alliance for Food Sovereignty in Africa, the Australian Food Sovereignty Alliance). In Canada, the National Farmers Union, Québec's Union Paysanne, Food Secure Canada, Indigenous movements, and others have brought food sovereignty into the national discourse through projects like the People's Food Policy (PFP, 2011; Levkoe \& Sheedy, 2018).

While there has been increasing enthusiasm surrounding food sovereignty, Binimelis et al. (2014) argue, "most organizations and governments working to promote it do not have the tools for monitoring and evaluating their projects or actions in this area, or simply to allow them to systematize policies from this perspective” (p. 327). In an attempt to develop food sovereignty indicators, they point to both the clarity of food sovereignty as a political and values-based concept and a clear guiding goal that supports and shapes a range of perspectives and outcomes founded on place-based considerations (p. 327). Using a process to develop food sovereignty indicators, Binimelis et al. (2014) argue that these processes can "contribute to providing political direction at different geographical scales. . . . At the same time, they favor the movement's self-reflexivity in its practices while supporting the collective shaping of future actions” (p. 324).

\section{Food systems report cards}

There are a number of approaches used to gather food systems information. Below the international scale, indicators tend to be more grounded in place-based priorities. For example, in 2010, the United Kingdom undertook a national initiative to develop sustainable food systems indicators through the Department for Environment, Food and Rural Affairs (DEFRA, 2010). Founded on the Food 2030 Strategy, the assessment includes indictors such as health, food affordability, food safety, productivity of agriculture, animal welfare, capacity building, and environmental aspects. The national-scale assessment developed by Gustafason et al. (2016) includes food nutrient adequacy, ecosystem stability, food affordability and availability, sociocultural wellbeing, resilience, food safety, and waste and loss reduction. In another example, Landert, Schader, Moschitz, \& Stolze (2017) demonstrate that adapting the Food and Agriculture Organization's Sustainability Pathways: Sustainability Assessments indicators in Basel, Switzerland, incorporated a number of indicators related to food sovereignty and Indigenous knowledge under the themes of cultural diversity and social well-being.

In Canada and the United States, there are many examples of report cards at the municipal and regional level that use a sustainable food systems approach. A few examples 
include: Assessing San Diego County Food System: Indicators for a More Secure Future (Ellsworth \& Feenstra, 2010); Community Food Security Indicators Report Card (SudburyManitoulin Food Security Network, 2005); Community Food Security Report Card (Thunder Bay and Area Food Strategy, 2015); Determining Food Access and Food Literacy: Indicators for the Ontario Food and Nutrition Strategy (Manafò, 2016). In another example, Feenstra, Jarmillo, McGrath, \& Grunnell (2005) identified 22 goals for sustainable food systems in California with community and academic partners.

More specifically, there are a number of indicator-based evaluations that apply food sovereignty principles. Internationally, the Global Network for the Right to Food and Nutrition uses food sovereignty principles to guide assessments of national food systems in more than 80 countries. Potential indicators include the extent of child marriage, degree of land concentration, political participation for the right to food, stunting, people living in rural areas, antidiscrimination laws, and people's sovereignty over natural resources. The indicators used depend on the information available in each country. Applying a more conceptual approach, an international-level assessment was developed through a process of literature review and expert consultation (Ortega-Cerdà \& Rivera Ferré, 2010). In this case, the researchers identified five themes with 35 sub-categories linked to 128 indicators as the basis for an international assessment. This process identified several data gaps that need to be filled to fully consider food sovereignty at the international scale.

To provide the basis for comparison, Binimelis et al. (2014) also assessed a local scale project in Catalan undertaken by Badal, Binimelis, Gamboa, Heras, \& Tendero (2011). The comparison of the two scales revealed that while there are common objectives, the projects diverge in terms of information gathered, with local projects adopting a place-based, community perspective and the other projects using either national or global lenses. In the case of Cuba, Reardon and Perez (2010) offer insights into indicator development in support of agroecology where they also apply a food sovereignty lens to small-holder farms. This work began with a literature review followed by participatory consultation to identify simple indicators that reflect the multiplicity of sustainability. This included indicators around environmental (e.g., Integrated Agrobiodiversity and Functional Diversity), economic (e.g., Land Equivalent Ratio, Household Food Production and Contribution to Community Food Supplies), and social (e.g., Commitment to Social Good, Gender Equity and Participation in MACAC) factors, as well as integrated factors (e.g., Access to and Control over Seeds). Tested with 400 farmers, their relevance is summarized as follows,

The development of indicators of food sovereignty, applicable at the smallholder farm level, provides a useful tool for identifying trends towards such a resilient agriculture. With this new tool at their disposal, more smallholder farmers and their allies will have the ability to evaluate the agroecosystem components currently hindering the emergence of food sovereignty (p. 920). 
Despite these many excellent examples of measuring sustainable food systems and more specifically food sovereignty, there is no report card that provides information about food system sustainability at the national level. Given this gap, we developed Food Counts: A Pan-Canadian Sustainable Food Systems Report Card using a food sovereignty framework. In the following section, we discuss the process of developing Food Counts and share some of the findings revealed by the report card.

\section{Food Counts: A pan-Canadian sustainable food systems report card}

The objective of the Food Counts report card was to establish a framework for benchmarking and assessing the state of Canada's food systems using available measures of social, environmental and economic well-being from a sustainability perspective. The report card used a series of indicators to better understand the interconnections within the food system to inform decisions about how to ensure it could be more healthy, equitable, and sustainable into the future. In consultation with a range of researchers and food movement organizations, the report card adopted food sovereignty as a crosscutting, multi-sectoral framework to assess how food systems function. The report card also highlighted the gaps in available indicators, pointing to new information needed to guarantee the right to adequate food, protect our water-based ecosystems, soil, and forests, and to include all people living in Canada as part of democratic deliberation. By providing practical information and a visionary framework, the report card is aimed at supporting food movement organizations, policy makers and researchers by providing access to relevant data. It is expected that over time, as new data becomes available, the report card could be enhanced as a metric of food systems sustainability.

Building the report card around food sovereignty provided a strong political and valuesbased focus that defined indicators that were practical, but also visionary. Unlike frameworks that take a narrow view of singular aspects of food systems, food sovereignty reframes food within a comprehensive, integrated systems perspective. Further, as a concept in evolution it demands critical reflexivity and engagement with social movements working for collective social change.

The framework used the six core pillars of food sovereignty developed at the Nyéléni Forum for Food Sovereignty (2007) (i.e., focuses on food for people, builds knowledge and skills, works with nature, values food providers, localizes food systems, puts control locally), as well as a seventh pillar (food is sacred) developed with members of the Indigenous Circle of the People’s Food Policy project (PFP, 2011).

\section{Developing Food Counts}

The first step to developing Food Counts was to conduct a scan of existing report cards and the different criteria and indicators they used. This enabled an assessment of the kinds of data available in Canada at the national level or at other scales that could be aggregated. From there, 
we developed a set of criteria to asses which data sources to include in the report card (See Table 1). Since the report card aimed to create a benchmark to assess changes in the food system over time, whether the data would be available in the future was a key consideration. It was also essential that the data be publicly accessible and understandable. Because of these criteria, the report card does not reflect a comprehensive set of food systems measures. For example, certain indicators were not selected and some were prioritized over others according to the validity and reliability of the data. We also avoided choosing indicators which would require significant primary data collection.

Table 1: Food Counts indicator selection criteria

\begin{tabular}{|l|l|}
\hline Scale-relevant & Data is available on a national/pan-Canadian scale \\
\hline Measurable & Indicator is quantifiable \\
\hline Available & Data is available to the public \\
\hline Cost-effective & Data is accessible with little monetary input \\
\hline Stable & Data is consistently collected and replicable \\
\hline Reliable/credible & Data collected is methodologically sound \\
\hline Understandable/usable & Indicator is easily interpreted and applicable \\
\hline Sensitive to change & Indicator responds to change over a reasonable length of time \\
\hline
\end{tabular}

The process began by building on our existing research including the initial iteration of Food Counts conducted by Blay-Palmer et al. (2008). We searched for indicators using Statistics Canada datasets, the Canadian national data collection agency that conducts a census including the Canadian Community Health Survey and the Census of Agriculture, and about 350 other surveys on a variety of social, environmental and economic aspects of Canadian life including municipal, regional, provincial, national, and international sources. We searched for indicators that were comparable to those we identified in our environmental scan using key word searches and subject browsing. We also searched well-known Canadian and international organizations that collect relevant data (e.g., the United Nations Food and Agriculture Organization, the Organization of Economic Cooperation and Development). The available indicators were then classified within the seven food sovereignty pillars, and information was recorded regarding the source of data, geographic scale, timeline for data collection, most recent data points, and whether or not the indicator met all eight of the selection criteria. Some indicator data was disaggregated across specific population groups to highlight the differential impact of current and historical policies. Finally, the data for the selected indicators were downloaded and organized in tabular format. Graphical representations of the data were produced.

For those indicators which we were able to extract historical data, we evaluated the data by noting if the trend showed a positive or negative change with respect to food sovereignty goals. We depicted these trends by indicating "getting better" and "getting worse" but we did not attempt to indicate what absolute values are most favourable. Due to certain considerations, it was difficult to determine whether trends were positive or negative for some indicators. In such 
cases, we labeled these indicators as a "mixed" interpretation. For many indicators, data was only available for one point in time. For these indicators, we expected that this data would continue to be collected on a regular basis and that current data points would act as a baseline for future reports. In all cases, the data represented the most recent time point in which the information was available at a national level. The availability of recent data varied depending on the data source.

To acquire feedback on the indicators selected, the food sovereignty framework, and the general Food Counts findings, we consulted with a wide range of food systems researchers and practitioner networks through roundtable conversations and individual meetings. This feedback was incorporated into the report card prior to its launch. For example, feedback pointed to missing indicators which informed the research process and data collection as well as the accompanying wish list indicators (i.e., desired indicators not currently available). Accompanying the online Food Counts report card, we developed a feedback form to collect additional comments and suggestions surrounding future iterations.

\section{Food Counts findings}

The final version of the Food Counts report card included six categories and 61 indicators (two of the seven food sovereignty pillars - localizes food systems and puts control locally - were synthesized). The indicators were organized into the categories and themes presented in Table 2 (the full list of categories, themes, indicators, and status are presented in Appendix 1).

Table 2: Indicator Categories and Themes

\begin{tabular}{|l|l|}
\hline Category & Theme and Number of Indicators Available \\
\hline Focuses on Food for People & food access (7); poverty and income (6) \\
\hline Values Food Providers & $\begin{array}{l}\text { farm characteristics (11); farm profitability (6); farm operator } \\
\text { characteristics (9); food worker characteristics (1); farm safety } \\
(1)\end{array}$ \\
\hline Works with Nature & $\begin{array}{l}\text { agriculture-related (9); ecosystem protection (3); compound } \\
\text { indices (4) }\end{array}$ \\
\hline $\begin{array}{l}\text { Localizes Food Systems and } \\
\text { Puts Control Locally }\end{array}$ & networks and policy initiatives (2); breastfeeding (1) \\
\hline Builds Knowledge and Skills & funded projects (1) \\
\hline Food is Sacred & $(0)$ \\
\hline
\end{tabular}

There were a number of indicators that we wanted to include in this Food Counts report card, but could not because sufficient data was unavailable or it required primary or secondary data collection and/or analysis. To identify these indicators, we created a Wish List that outlines knowledge gaps that, if filled, could support a more comprehensive understanding of our food 
system. Some of the major themes that we identified included: food access, poverty/income, local food processing and purchasing, networks and policy initiatives, food literacy, and farmer education (see Appendix 2 for a summary of the Wish List themes and indicators). In addition to the Wish List, it could be important to operationalize indicators to assess the following areas: wild food resources, wild fisheries and aquaculture, cultural dimensions of food, corporate concentration in the food system, recycling of food packaging, food labelling, and advertising.

\section{Discussion: Whither food systems indicators?}

The Food Counts report card illuminates the ways that indicators can provide practical information to better understand the current state of food systems. Food Counts brought together a range of data using a comprehensive, pan-Canadian food systems lens in a way that had not been done before. Drawing on a food sovereignty framework that inherently implies principles of sustainability, Food Counts makes food systems' realities visable using measurable, available, stable, and reliable national-scale indicators, which provide baseline measurements. For researchers and food movement organizations, without the capacity to collect and consolidate this kind of data on their own, the report card is an extremely valuable tool to initiate dialogue, inform policy and program development, and assist with strategic planning and advocacy. The report helps to make food systems realities more transparent and fosters more informed discussions about what kind of food system Canadians want. Furthermore, Food Counts provides a way to dissolve boundaries as we identify the "politics of policy indicators" (Bauler, 2015, p. 44). Adopting food sovereignty as a guiding framework opens a pathway to reframe the way we understand food as part of integrated and interdependent systems. By identifying relevant indicators, Food Counts highlights connections between a range of interrelated issues that inform pressing social and ecological concerns such as climate change, food and nutrition security, white supremacy, patriarchy, poverty, to name only a few. Further, as Food Counts highlights potential leverage points for change and potential trade-offs it can contribute to initiatives working towards more socially just, ecologically regenerative, and economically localized food systems.

Beyond this more obvious value, the Food Counts report card makes it clear that there are major gaps in the data available to understand the complex and interrelated nature of food systems. For example, the fact that there are no indicators available within the food is sacred category illustrates the kinds of information that is valued—or not valued — through public data collection. Our Wish List of 33 indicators (and many more that could be named) highlights just some of these gaps. Currently, data is collected at the national level for a particular purpose and by particular interested parties (e.g., governments, corporations, private consultants, universities). Many of these indicators are collected to understand economic strengths or weaknesses, to indicate areas to boost agricultural exports, or to identify new market opportunities. The indicators presented in Food Counts point to several shortcomings in data 
availability. For example, despite serious challenges within Indigenous food systems (e.g., food access, food insecurity and high levels of diet-related disease) (Council of Canadian Academies, 2014) no data is collected at the national level to show paths forward that might lead to strengthening traditional food systems and food self-determination. Further, most government data in Canada is not collected on First Nation's reserves, which misses this important, underserved segment of our population. Some of this data may be accessible for those with more resources and capacity, such as the means to purchase data from government- or industrycompiled research. With additional and sustained capacity (e.g., human and financial resources), original data could be collected to fill these gaps. Relying on publicly accessible census data that is only collected every five years creates barriers to what we can know and share. Another limitation to using government data is that in 2010, the Conservative majority government cancelled the mandatory long-form census, leaving a major gap in publicly available data in Canada (the census was reinstated in 2015 when the Liberal government was elected).

Despite the limitations of available data, Food Counts provides an opportunity to critically reflect on the broader questions of how and whether to use indicators to measure food systems. In other words, report cards can be valuable tools but must be used with caution since it is impossible to capture the complexity of food systems dynamics with a series of static indicators. Despite the broader message of taking an interrelated systems approach, there is a risk of readers focusing on particular indicators to draw erroneous conclusions. For example, in a published opinion piece responding to Food Counts, a prominent Canadian editor wrote,

... the document [Food Counts] is actually dedicated to making food more expensive and keeping farm industry profits low. ... This upside-down report card repeatedly hands out low scores to any evidence showing farms are getting larger, more productive and more profitable. The preferred objective appears to be a nostalgic vision of a country filled with small, inefficient family farms - a moo, moo here and a cluck, cluck there. ... Even more disconcerting is the pseudo-religious tone to what's supposed to be a piece of serious academic advice for Ottawa. 'Food cannot be commodified,' Blay-Palmer writes. 'Food is sacred.' This is obvious and dangerous nonsense (Taylor, 2017).

This response displays not only a hasty reaction to an assessment of particular indicators, but also an extremely narrow perspective of food as serving only as sustenance and having economic value. In his article, Taylor ignores the long-term economic, ecological and social implications of a corporate-controlled, industrial farming sector (Patel, 2007). He also fails to recognize the ways that food was/is used as a tool of colonialism and Indigenous genocide (Daschuk, 2013). Instead, we suggest that a critical reflection of Food Counts might offer an opportunity for educating about the complexity of food systems and for food to become a response to a range of challenges. 
The reliance on quantifiable data risks over-simplifying certain realities and ignoring the interactions and interdependencies of food systems at the heart of human and ecological relationships. Indicators tend to privilege scientific expertise (e.g., numbers) over traditional and/or experiential knowledge. This reinforces the reductionist nature of using data to quantify food systems and misses the richness of community-level experiences. Thus, while not dismissing them completely, we must put report cards, like Food Counts, in context and reflect on the broader value of using indicators to measure food systems and ask what they may obscure in the process. The response to this critical reflection can identify the way other forms of research and methodologies (e.g., case studies) might provide insights into experiences and initiatives that can contribute to transformational change.

Most report cards make implicit assumptions about the meaning and value of certain indicators. While we attempted to identify the status of the various indicators in Food Counts based on what the data says, we recognize that it is extremely difficult to make assessments on a set of numbers without knowing and understanding the deeper context of each response. All data points are complicated, questionable, political and ripe with assumptions. For example, obesity is a contested concept and research has shown that body size is not necessarily related to issues of health (Beausoleil \& Ward, 2009). In another example, the fruit and vegetable consumption by Indigenous people is complicated. Through the nutrition transition (Martin \& Amos, 2016), Indigenous diets (especially in the north) have been radically shifted by colonialism. The goal of increasing non-traditional foods is problematic and must be reassessed in the context of the broader project of Indigenous rights and reconciliation. Many have argued that Indigenous food sovereignty means returning land, nation-to-nation relationships, and reviving traditional food practices (Morrison, 2011). In many cases, more vegetable consumption would mean a shift away from traditional food systems towards a colonial diet. When report cards measure these kinds of instances, they often predetermine intended outcomes that may be antithetical to transformative change. Food Counts, along with this critical reflection on indicators, helps to move beyond a narrow quantitative valuation (i.e., "bean counting”) touted by neoliberalism and attempts to value community contributions to food systems.

\section{Conclusion}

Beyond its explicit value, the Food Counts report card is an opportunity to reflect on the limitations of data and the ways it can, and is, being used to shape our lives. We share this description of Food Counts as a tool that identifies a valuable set of data. In addition, we present this critical reflection as a mirror to reflect the counterproductive nature of quantifying complex food systems.

These reflections are particularly important considering the Canadian government's development of a national food policy. Once established, this initiative will require a monitoring and reporting system that includes baseline measurements as well as ongoing information 
collection to inform its progress and impact. Our analysis of food systems indicators and Food Counts raises important questions about how we have framed food system considerations to date and what needs to change. For example, it is clear from existing government programs that there is a heavy emphasis on producing commodity crops and developing export markets for food in Canada (Wiebe, 2016). This has come at the expense of producing healthy food for the Canadian population and considerations of long-term soil health and ecosystem sustainability. Also, Canada's Food Guide, which contains recommendations for healthy eating, has failed to recognize the negative impacts of highly processed food on individual, social, and environmental health, and have been heavily influenced by corporate lobbying (de Villa, 2017).

Given ongoing efforts into developing a national food policy for Canada, Food Counts offers important considerations that need to be part of the policy development discussions. Food sovereignty provides a framing that considers food as part of an interrelated system along with ways to conceptualize available indicators. It also highlights information gaps and areas where additional data could be prioritized and collected. For example, better consideration is needed around the role of food in many cultures (and specifically in Indigenous communities), the implications of poverty on food insecurity, and the social, ecological, and economic value of alternatives to industrial, profit-driven agriculture and fishing. Our analysis also provides important cautions around institutionalizing indicators for a national food policy. While providing valuable information, it is essential to establish platforms for ongoing critical reflection among the range of food systems actors to enable collaboration across sectors and scales and to provide citizen oversight for government process.

Even beyond the report card itself, using food sovereignty as a framework to assess the Canadian food system is a way for food movements to speak across sectors, scales and places. For researchers and practitioners across the globe, it also presents a conundrum regarding the commonalities and divergences between sustainability and food sovereignty as an opening for increased understanding, dialogue and action across food movements: Are sustainability and food sovereignty complementary or is there some dissonance between the two? Over the coming years, we will continue to develop the Food Counts report card and critically asses its value. As the report card is shared more broadly and feedback is submitted from the online form, we will continue to assess how to move it forward.

Acknowledgments: The authors would like to thank Rachael Lefebvre for her tireless work and support developing the Food Counts report card. We would also like to thank the Canadian Association for Food Studies, Food Secure Canada and the academic and community partners that offered insight into the development of the report card as well as providing feedback on the specific indicators and general framework. This project was funded through the Social Science and Humanities Research Council of Canada Partnership Project, Food: Locally Embedded, Globally Engaged (FLEdGE). 


\section{References}

Anderson, M.D. (2008). Rights-based food systems and the goals of food systems reform. Agriculture and Human Values, 25(4), 593-608.

Badal, M., Binimelis, R., Gamboa, G., Heras, M., \& Tendero, G. (2011). Arran de terra. Indicadors participatius de Sobirania Alimentària a Catalunya. Barcelona: Associació Entrepobles i Institut d’Economia Ecològica i Ecologia Política.

Beaulieu, M. (2015). Demographic changes in Canadian agriculture. Statistics Canada. Available at http://www.statcan.gc.ca/pub/96-325-x/2014001/article/11905-eng.htm. Accessed January 28, 2017.

Beck, U. (2005). The risk society and beyond: Critical issues for social theory. In B. Adam, U. Beck, \& J. Loon (Eds.), The risk society revisited (pp. 211-229). Thousand Oaks: Sage.

Bauler, T. (2012). An analytical framework to discuss the usability of (environmental) indicators for policy. Ecological Indicators, 17, 38-45.

Beausoleil, N., \& Wad, P. (2009). Fat panic in Canadian public health policy. Radical Psychology: A Journal of Psychology, Politics \& Radicalism, 8(1), 5.

Bell, S., \& Morse, S. (2011). An analysis of the factors influencing the use of indicators in the European Union. Local Environment, 3(2), 281-302.

Binimelis, R., Rivera-Ferre, M. G., Tendero, G., Badal, M., Heras, M., Gamboa, G., \& Ortega, M. (2014). Adapting established instruments to build useful food sovereignty indicators. Development Studies Research, 1(1), 324-339.

Blay-Palmer, A., Turner, J., \& Kornelson, S. (2008). Quantifying food systems: Assessing sustainability in the Canadian context. In M. Koc, J. Sumner, \& A. Winson (Eds.), Critical Perspectives in Food Studies (pp. 337-358). Toronto: Oxford University Press.

Clapp, J. \& Fuchs, D. (Eds.). (2009). Corporate power in global agrifood governance. Cambridge: MIT Press.

Climate Smart Agriculture CONCERNS. (2015). COP21 Statement. Available at http://www.climatesmartagconcerns.info/cop21-statement.html. Accessed September 29, 2017.

Council of Canadian Academies. Expert Panel on the State of Knowledge of Food Security in Northern Canada. (2014). Aboriginal food security in Northern Canada: An assessment of the state of knowledge. Ottawa: Council of Canadian Academies.

Daschuk, J. (2013). Clearing the plains: Disease, politics of starvation, and the loss of aboriginal life. Regina: University of Regina Press. 
[DEFRA] Department for Environment, Food and Rural Affairs. (2011). Indicators for a sustainable food system. DEFRA: York, UK.

De Villa, E. (2018). Sustainable Diets - Healthy Eating, Healthy Planet. Report for Action. HL23.1. City of Toronto. Available at https://www.toronto.ca/legdocs/mmis/2017/hl/bgrd/backgroundfile-108989.pdf. Accessed March 10, 2018.

Diabetes Canada. (2009). Economic Tsunami: The Cost of Diabetes in Canada. Available at http://www.diabetes.ca/publications-newsletters/advocacy-reports/economic-tsunami-thecost-of-diabetes-in-canada. Accessed November 7, 2017.

Ellsworth, S., \& Feenstra, G. (2010). Assessing the San Diego County food system: Indicators for a more food secure future. Davis, CA: Agricultural Sustainability Institute, University of California Research and Education Program.

Ericksen, P., Stewart, B., Dixon, J., Barling, D., Loring, P. Anderson, M., \& Ingram, J. (2010a). The value of a food systems approach. In J. Ingram, P. Ericksen \& D. Liverman (Eds.), Food Security and Global Environmental Change (pp. 25-45). London: Earthscan.

Ericksen, P., Stewart, B., Eriksen, S., Tschakert, P., Sabates-Wheeler, R., Hansen, J., \& Thornton, P. (2010b). Adapting food systems. In J. Ingram, P. Ericksen, \& D. Liverman (Eds.), Food Security and Global Environmental Change (pp. 115-143). London: Earthscan.

[FAO] Food and Agriculture Organization. (1991). State of food insecurity in the world (SOFI), Food insecurity: When people must live with hunger and fear starvation. http://www.fao.org/NEWS/1999/img/SOFI99-E.PDF. Accessed September 1, 2017.

Feenstra, G., Jarmillo, C., McGrath, S., \& Grunnell, A. (2005). Purpose indicators for sustainable food systems. Ecotrust-Vivid Picture Project. Available at www.VividPicture.net. Accessed September 1, 2017.

FIAN. 2016. The right to food and nutrition security: Beyond food security towards food sovereignty. Available at http://www.fian.org/fileadmin/media/Publications/30th_Anniversary/Right_to_Food_and Nutrition_Beyond_Food_Security_towards_Food_Sovereignty.pdf. Accessed September 30, 2017.

Food Banks Canada (2016). Hunger Count. Available at https://www.foodbankscanada.ca/HungerCount. Accessed November 7, 2017.

Forster, T., \& Mathieson, E. (2016). Territorial food systems: Protecting the rural and localizing human rights accountability. Right to Food and Nutrition. Available at http://www.righttofoodandnutrition.org/files/Watch_2016_Article_4_eng_Territorial\%20F ood\%20Systems.pdf. Accessed September 31, 2017. 
Garnett, T., \& Godfray, C. (2012). Sustainable intensification in agriculture. Navigating a course through competing food system priorities. Food Climate Research Network and the Oxford Martin Programme on the Future of Food. Oxford, UK: University of Oxford, UK.

GRAIN. (2011). Food and climate change: The forgotten link. Against the Grain. Available from: http://www.grain.org/articles. Accessed September 1, 2017.

Gustafson, D., Gutman, A., Leet, W., Drewnowski, A., Fanzo, J., \& Ingram, J. (2016). Seven food system metrics of sustainable nutrition security. Sustainability, 8, 196-213.

Hacking, I. (2007). Kinds of people: Moving targets. Proceedings of the British Academy, 151, 285-318.

Hamm, M. (2015). City region food systems - Part I - Conceptualization. Food Climate Research Network Blog. Available at: http://www.fcrn.org.uk/fcrnblogs/michaelwhamm/city-region-food-systems-\%E2\%80\%93-part-i-\%E2\%80\%93conceptualization. Accessed September 27, 2017.

Hezri, A., \& Dovers, S. (2006). Sustainability indicators, policy and governance: Issues for ecological economics. Ecological Economics, 60, 86-99.

Howard, P.H. (2016). Concentration and power in the food system: Who controls what we eat? New York: Bloomsbury Academic.

[IPES-Food] International Panel of Experts on Sustainable Food Systems. (2015). IPES-Food and the new science of sustainable food systems: Who shapes food systems, and who has a say in how they are reformed? Available at http://www.ipesfood.org/images/Reports/IPES_report01_1505_web_br_pages.pdf. Accessed September 28, 2017.

[IPES-Food] International Panel of Experts on Sustainable Food Systems. (2016). From uniformity to diversity: A paradigm shift from industrial agriculture to diversified agroecological systems. Available at http://www.ipesfood.org/images/Reports/UniformityToDiversity_FullReport.pdf. Accessed September 28, 2017.

Kloppenburg, J., Jr., Lezberg, S., De Master, K., Stevenson, S., \& Hendrickson, J. (2000). Tasting food, tasting sustainability: Defining the attributes of an alternative food system with competent, ordinary people. Human Organization, 59(2), 177-186.

Le Vallée, J.C., \& Grant, M. (2016). Canada’s Food Report Card 2015: International Comparison. Conference Board of Canada. Available at http://www.conferenceboard.ca/elibrary/abstract.aspx?did=7617\&AspxAutoDetectCookieSupport=1. Accessed November 7, 2017.

Landert, J., Schader C, Moschitz H, \& Stolze M. (2017). A holistic sustainability assessment method for urban food system governance. Sustainability, 9(4), 490-511. 
Levkoe, C. Z., \& Sheedy, A. (2017). A people-centred approach to food policy making: Lessons from Canada’s People’s Food Policy project. Journal of Hunger \& Environmental Nutrition, 1-21.

Levkoe, C.Z., \& Wilson, A. (2017). The promise of a National Food Policy for Canada. The Conversation. Available at https://theconversation.com/the-promise-of-a-national-foodpolicy-for-canada-80386. Accessed November 6, 2017.

Manafò, E. (2016). Determining Food Access and Food Literacy: Indicators for the Ontario Food and Nutrition Strategy. Ontario Food and Nutrition Strategy. Available at https://sustainontario.com/custom/uploads/2012/04/OFNS-Final-Report-v3.1-April-82016.pdf. Accessed September 1, 2017.

Marsden, T. (2010). Mobilizing the region eco-economy: Evolving webs of agri-food and rural development in the UK. Cambridge Journal of Regions, Economy and Society, 3, 225-44.

Martin, D., \& Amos, M. (2016). What constitutes good food? Towards a critical Indigenous perspective of food and health. In M. Koc, J. Sumner, \& A. Winson (Eds.). Critical Perspectives in Food Studies (Second Edition) (pp. 205-220). Toronto: Oxford.

McIntyre, B. D., Herren, H. R., Wakhungu, J., \& Watson, R. T. (2009). Agriculture at a crossroads. The International Assessment of Agricultural Knowledge, Science and Technology for Development. Washington DC: Island Press.

Morrison, D. (2011). Indigenous food sovereignty: A model for social learning. In H. Wittman, A. Desmarais, \& N. Wiebe (Eds.). Food sovereignty in Canada: Creating just and sustainable food systems (pp. 97-13). Halifax: Fernwood Publishing.

Nyéléni Forum for Food Sovereignty. (2007). Declaration of Nyéléni. Sélingué, Mali. Available at https://nyeleni.org/spip.php?article290. Accessed 13 April 2017.

Ortega Cerdà, M., \& Rivera-Ferre, M.G. (2010). Indicadores internacionales de Soberanía Alimentaria. Nuevas herramientas para una nueva agricultura. Revibec: revista de la Red Iberoamericana de Economia Ecológica, 14, 0053-77.

Patel, R. (2007). Stuffed and starved: Markets, power and the hidden battle for the world's food system. Toronto: Harper Collins.

Patel, R. (2009). Food sovereignty. The Journal of Peasant Studies, 36(3), 663- 706.

[PFP] People's Food Policy. (2011). Setting the table: a people's food policy for Canada. Ottawa: People’s Food Policy Project. Available at: https://foodsecurecanada.org/peoplefood-policy. Accessed April 27, 2017. 
Pullman, M.E., Maloni, M.J., \& Carter, C.R. (2009). Food for thought: Social versus environmental sustainability practices and performance outcomes. Journal of Supply Chain Management, 45(4), 38-54.

Sage C. (2001). Environment and food. New York: Routledge.

Schader, C., Baumgart, L., Landert, J., Muller, A., Ssebunya, B., Blockeel, J., Weisshaidinger, R., Petrasek, R., Mészáros, D., Padel, S., et al. (2016). Using the sustainability monitoring and assessment routine (SMART) for the systematic analysis of trade-offs and synergies between sustainability dimensions and themes at farm level. Sustainability 8(3), 274.

Simón Reardon, J. A., \& Pérez, R.A. (2010). Agroecology and the development of indicators of food sovereignty in Cuban food systems. Journal of Sustainable Agriculture, 34(8), 907922.

Sudbury-Manitoulin Food Security Network. (2005). Community Food Security Indicators Report Card. City of Greater Sudbury. Available at http://foodshedproject.ca/wpcontent/uploads/2015/12/2007-FSN-Indicators-Baseline-2005-Report-Card.pdf. Accessed September 28, 2017.

Sustainable Development Solutions Network (UN). (2015). Indicators and a monitoring framework for sustainable development goals: Launching a data revolution for the SDGs.

Available at http://unsdsn.org/wp-content/uploads/2015/05/150612-FINAL-SDSN-IndicatorReport1.pdf. Accessed September 30, 2017.

Tanguay, G., Rajaonson, J., Lefebvre, J-F., \& Lanoie, P. (2010). Measuring the sustainability of cities: An analysis of the use of local indicators. Ecological Indicators, 10(2), 407-418.

Tarasuk, V., Dachner, N., \& Loopstra, R. (2014). Food banks, welfare, and food insecurity in Canada. British Food Journal, 116(9), 1405-1417.

Taylor, P. (2017). Manure belongs on farms, not food policies. Waterloo Region Record. https://www.therecord.com/opinion-story/7407760-manure-belongs-on-farms-not-foodpolicies/. Accessed September 27, 2017.

The Economist Group. (2016). Global Food Security Index. Available at http://foodsecurityindex.eiu.com/. Accessed November 7, 2017.

Thunder Bay and Area Food Strategy. (2015). Connecting food and community. Available at http://tbfoodstrategy.com/files/FoodStrategy_2014_LoRes_WEB.pdf. Accessed September 28, 2017.

Weber, M. (2006). Foresight and adaptive planning as complementary elements in anticipatory policymaking: A conceptual and methodological approach. In J. Voß, D. Bauknecht, \& R. Kemp (Eds.), Reflexive governance for sustainable development (pp. 189-221). Northampton: Edward Elgar. 
Wiebe, N. (2016). Crisis in the food system: The farm crisis. In M. Koc, J. Sumner, \& A. Winson (Eds.), Critical Perspectives in Food Studies (pp. 138-153). Toronto: Oxford University Press.

Wittman, H., Desmarais, A.A., \& Wiebe, N. (Eds.). (2010). Food sovereignty: Reconnecting food, nature and community. Halifax: Fernwood. 


\section{Appendix 1: Summary of the Food Counts Indicators}

\section{Focuses on Food for People}

This principle speaks to putting people's need for food at the centre of policies and insists that food is more than just a commodity.

\begin{tabular}{|l|l|l|}
\hline Theme & Indicator & Status \\
\hline \multirow{5}{*}{ Food access } & 1. Fruit \& vegetable consumption & Getting worse \\
\cline { 2 - 3 } & 2. Fruit \& vegetable consumption by Aboriginal identity & $\begin{array}{l}\text { One point in time } \\
\text { data }\end{array}$ \\
\cline { 2 - 3 } & 3. Food availability & Mixed \\
\cline { 2 - 3 } & 4. Food expenditures & Mixed \\
\cline { 2 - 3 } & 5. Consumer price index & Getting worse \\
\cline { 2 - 3 } & 6. Food waste & $\begin{array}{l}\text { One point in time } \\
\text { data }\end{array}$ \\
\cline { 2 - 3 } & 7. Food safety & Not improving \\
\hline \multirow{5}{*}{$\begin{array}{l}\text { Poverty/ } \\
\text { income }\end{array}$} & 8. People living below the low income measure & Getting better \\
\cline { 2 - 3 } & 9. Median annual family income & Mixed \\
\cline { 2 - 3 } & 10. Unemployment rate & Getting better \\
\cline { 2 - 3 } & 11. Food insecurity by household composition & Getting worse \\
\cline { 2 - 3 } & 12. Food insecurity by Aboriginal identity & Getting worse \\
\cline { 2 - 3 } & 13. Food bank use & Getting worse \\
\hline
\end{tabular}




\section{Values Food Providers}

This principle speaks to respecting the work of all food providers and supporting sustainable livelihoods.

\begin{tabular}{|c|c|c|}
\hline Theme & Indicator & Status \\
\hline \multirow{11}{*}{$\begin{array}{l}\text { Farm } \\
\text { characteristics }\end{array}$} & 14. Number of farms & Getting worse \\
\hline & 15. Farm size & Getting worse \\
\hline & 16. Farm operating management & Getting worse \\
\hline & 17. Farm land tenure & Getting worse \\
\hline & 18. Type of farm & One point in time data \\
\hline & 19. Farms by commodities & Mixed \\
\hline & 20. Farm area use of land & Mixed \\
\hline & 21. Production of livestock & Mixed \\
\hline & 22. Production of poultry & Mixed \\
\hline & 23. Production of eggs & Getting worse \\
\hline & 24. Number of people employed in agriculture & Mixed \\
\hline \multirow{6}{*}{$\begin{array}{l}\text { Farm } \\
\text { profitability }\end{array}$} & 25. Gross farm receipts & Mixed \\
\hline & 26. Net farm income & Mixed \\
\hline & 27. Farm debt & Getting worse \\
\hline & 28. Farm capital & Getting better \\
\hline & 29. Average hourly and weekly wages in agriculture & Getting better \\
\hline & 30. Household income class for farm population & One point in time data \\
\hline \multirow{9}{*}{ Characteristics } & 31. Number of farm operators & Getting worse \\
\hline & 32. Age of farm operators & Getting worse \\
\hline & 33. Sex of farm operators & Mixed \\
\hline & 34. Country of birth of farm operators & One point in time data \\
\hline & 35. Farm operators with paid non-farm work & Mixed \\
\hline & 36. Farm operator activity in labour force & One point in time data \\
\hline & $\begin{array}{l}\text { 37. Number of hours worked per week for farm } \\
\text { operators }\end{array}$ & One point in time data \\
\hline & 38. Distribution of farm population by location & One point in time data \\
\hline & 39. Number of people in SAWP program & Getting worse \\
\hline $\begin{array}{l}\begin{array}{l}\text { Food worker } \\
\text { characteristics }\end{array} \\
\end{array}$ & $\begin{array}{l}\text { 40. Number of employees in food service, wholesale } \\
\text { and manufacturing }\end{array}$ & Mixed \\
\hline Farm safety & 41. Agricultural fatalities & Getting better \\
\hline
\end{tabular}




\section{Works with Nature}

This principle speaks to optimizing the contributions of ecosystems and improving ecosystem resilience.

\begin{tabular}{|c|c|c|}
\hline Theme & Indicator & Status \\
\hline \multirow{9}{*}{$\begin{array}{l}\text { Agriculture- } \\
\text { related }\end{array}$} & 42. Land management inputs on farms & Getting worse \\
\hline & 43. Farm water conservation practices & Getting better \\
\hline & 44. Water use, by industry & Getting better \\
\hline & 45. Freshwater quality, by land use & One point in time data \\
\hline & 46. Agricultural emissions & Getting worse \\
\hline & 47. Farms reporting organic products for sale & Getting better \\
\hline & $\begin{array}{l}\text { 48. Households participating in composting kitchen } \\
\text { waste }\end{array}$ & Getting better \\
\hline & 49. Hectares of forest deforested from agriculture & Getting better \\
\hline & 50. Preservation land practices & One point in time data \\
\hline \multirow{3}{*}{$\begin{array}{l}\text { Ecosystem } \\
\text { protection }\end{array}$} & 51. Protected land area & Getting better \\
\hline & 52. Protected marine area & Getting better \\
\hline & 53. Major sh stocks status & Stable \\
\hline \multirow{4}{*}{$\begin{array}{l}\text { Compound } \\
\text { indices }\end{array}$} & 54. Biodiversity index & Getting better \\
\hline & 55. Soil quality index & Getting better \\
\hline & 56. Water quality index & Getting worse \\
\hline & 57. Air quality index & Getting better \\
\hline
\end{tabular}




\section{Localizes Food Systems and Puts Control Locally}

The localizes food systems principle speaks to reducing the distance between food providers and consumers, resisting dependency on remote and unaccountable corporations, and rejecting dumping and inappropriate food aid. The puts control locally principle speaks to placing control in the hands of local food providers, recognizing the need to inhabit and to share territories and rejects the privatization of natural resources.

\begin{tabular}{|l|l|l|}
\hline Theme & Indicator & Status \\
\hline \multirow{2}{*}{$\begin{array}{l}\text { Networks and } \\
\text { policy initiatives }\end{array}$} & 58. Number of municipal food policy initiatives & One point in time data \\
\cline { 2 - 3 } & 59. Number of food system networks & One point in time data \\
\hline Breastfeeding & 60. Breastfeeding initiation and maintenance & Mixed \\
\hline
\end{tabular}

\section{Builds Knowledge and Skills}

This principle speaks to building on traditional knowledge, using research to support and pass on this knowledge to future generations and the rejection of technologies that undermine or contaminate local food systems.

\begin{tabular}{|l|l|l|}
\hline Theme & Indicator & Status \\
\hline Funded projects & $\begin{array}{l}\text { 61. Number of food system related awarded grants } \\
\text { through federal government granting agencies }\end{array}$ & Mixed \\
\hline
\end{tabular}

\section{Food is Sacred}

This principle speaks to recognizing that food is a gift of life, and should not be squandered. It asserts that food cannot be commodified.

We did not find any indicators which we felt could represent this principle. 


\section{Appendix 2: Wish List}

\section{Summary of Wish List Indicators}

\begin{tabular}{|c|c|}
\hline Theme & Indicator \\
\hline \multirow{3}{*}{ Food access } & Cost of public transportation \\
\hline & Monthly cost of a nutritious food basket per person \\
\hline & Number of school meal programs \\
\hline \multirow{2}{*}{ Poverty/income } & Social assistance rates \\
\hline & Social housing availability/waitlists \\
\hline \multirow{4}{*}{ Agriculture- related } & Farm animal welfare certification \\
\hline & $\begin{array}{l}\text { Proportion of energy used for growing, storing, processing food that } \\
\text { is renewable }\end{array}$ \\
\hline & Proportion of various crops that are genetically modified \\
\hline & Area dedicated to urban agriculture \\
\hline \multirow[t]{2}{*}{ Local food processing } & $\begin{array}{l}\text { Various measures of local food processing (e.g., number of } \\
\text { abattoirs, number of businesses milling flour) }\end{array}$ \\
\hline & Number of food hubs \\
\hline \multirow{4}{*}{ Local food purchasing } & Direct farm-to-consumer sales \\
\hline & Percentage of consumers buying local food \\
\hline & Institutional local food procurement \\
\hline & Redundant trade \\
\hline \multirow{9}{*}{ Participatory initiatives } & Number of community supported agriculture partnerships (CSAs) \\
\hline & Number of farmer markets \\
\hline & Number of farm to school programs \\
\hline & Number of school gardens and community gardens \\
\hline & Number of student nutrition programs \\
\hline & Number of community kitchens \\
\hline & Number of seed banks and seed libraries \\
\hline & Number of urban food harvesting projects \\
\hline & Number of food and farming co-operatives \\
\hline $\begin{array}{l}\text { Networks and policy } \\
\text { initiatives }\end{array}$ & Number of food systems organizations/associations \\
\hline \multirow{3}{*}{$\begin{array}{l}\text { Access to primary food } \\
\text { production resources }\end{array}$} & Land for small-scale producers and industries related to agriculture \\
\hline & Access/control of seeds \\
\hline & Incidence of land grabbing \\
\hline Food literacy & Food skills and food literacy programs \\
\hline \multirow{3}{*}{ Farmer education } & Funding for farmer-led research \\
\hline & Federal training and support programs for new farmers \\
\hline & Participatory plant research and breeding \\
\hline $\begin{array}{l}\text { Elementary/ secondary } \\
\text { education }\end{array}$ & Number of food system education programs, courses, curriculum \\
\hline
\end{tabular}

